\title{
Post-kala-azar dermal leishmaniasis: a case report strikingly resembling lepromatous leprosy
}

\author{
V RAMESH, * UMA SAXENA, R S MISRA \\ \& A MUKHERJEE† \\ Department of Dermatology and Leprology, and $\dagger$ Institute of \\ Pathology (ICMR), Safdarjung Hospital, New Delhi, India
}

\author{
Accepted for publication 12 October 1990
}

\begin{abstract}
Summary An adult man with post-kala-azar dermal leishmaniasis who had lessons distributed in a manner strikingly similar to lepromatous leprosy is described. He was mistakenly treated with multidrug therapy as recommended by the WHO Expert Committee on leprosy. All investigations including slit-skin smears, histopathology, culture for Leishmania donovani and an indirect fluorescent antibody test to confirm post-kala-azar dermal leishmaniasis proved futile. The diagnosis was ultimately based on the previous history of kala-azar, the absence of other disorders which were ruled out by relevant laboratory tests and the good therapeutic response to sodium antimony gluconate. The epidemiological significance of this case and the salient points to distinguish this condition from leprosy are discussed.
\end{abstract}

\section{Introduction}

Post-kala-azar dermal leishmaniasis (PKDL) is an important condition to be considered in the diagnosis of leprosy, particularly lepromatous or near lepromatous leprosy (LL). Thus PKDL finds a place in all the standard books on leprosy and it is necessary for all workers in the field of leprosy to be aware of this disorder, more so for people in countries where kala-azar is prevalent. In India, kala-azar is endemic in the eastern states, and with increasing migration to seek jobs, a stray case of PKDL can be easily mistaken for leprosy, which is prevalent throughout the country. This report deals with a patient of PKDL whose symptoms strikingly resembled LL. The factors that led to misdiagnosis and the noteworthy points of difference between PKDL and LL are re-emphasized.

\section{Case report}

A 50-year-old man employed in a factory who had migrated to Delhi at the age of 20 from his native town in eastern Uttar Pradesh came with nodular eruptions of 3 years'

*Correspondence: Sector 12/1082, R K Puram, New Delhi 110 022, India. 
duration. They had started as asymptomatic red papules and plaques on the face and nape of neck. In 4-5 months the condition had spread to the rest of the body including the extremities. Some plaques on the dorsa of the hands had ulcerated. Deeper interrogation disclosed that he had intermittent fever followed by splenomegaly at the age of 14 which lasted for 1 year. This was diagnosed as kala-azar and had subsided on taking treatment from the local doctor. Presently, the nodular eruptions were diagnosed as LL by a dermatologist and biopsied. The report had revealed a dermal infiltrate of lymphocytes, histiocytes and plasma cells, and occasional fragmented acid-fast bacilli (AFB) on ZiehlNeelsen's stain. The patient was given WHO recommended multidrug therapy (MDT) comprising rifampicin, clofazimine and dapsone. ${ }^{1}$ After a year there was no relief and some lesions had increased in size. Taking the advice of another dermatologist the patient continued MDT for 1 more year and af ter 2 years of therapy he was referred to our clinic with no inprovement in his condition. On physical examination the patient was not anaemic, nonicteric and the skin had a brownish hue with ichthyosis of the extremities indicating the oral intake of clofazimine. Cutaneous examination revealed circumscribed, firm, nontender papules and plaques, and nodules of varying sizes on the forehead, chin, cheeks, lip margins, neck, trunk and the extremities. The earlobes and cheeks were infiltrated (Figure 1). The truncal lesions showed faint hypopigmentation in the centre and transverse fissures resulting in ulcers were seen on the plaques of the small joints of the dorsa of hands (Figure 2). Palms and soles were involved. The scrotum, penis and perianal area were infiltrated with multiple papulonodules. The mucosae appeared normal. There was no sensory deficit and the peripheral nerves felt normal. The lymph nodes, liver and spleen were not enlarged.

The following investigations were normal: blood and urinalysis, lipid profile, serum proteins, peripheral smear for abnormal cells, bone marrow puncture, liver function tests, venereal disease research laboratory test, Treponema pallidum hemagglutination test, chest X-ray and ECG. A Mantoux test read $4 \mathrm{~mm} \times 6 \mathrm{~mm}$. Serum tested for antibodies by the indirect fluorescent antibody test using a leishmania antigen was negative. Slit-skin

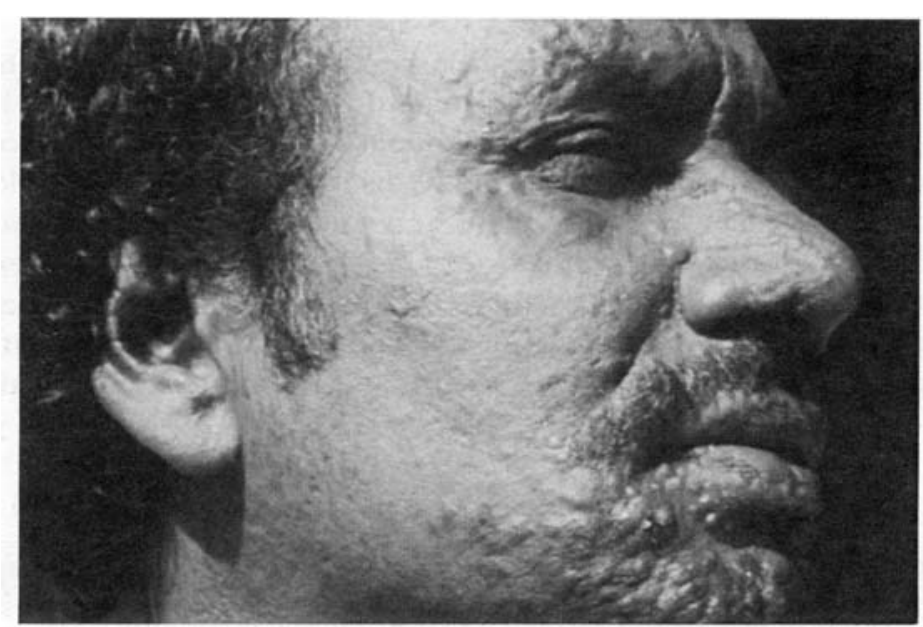

Figure 1 . 


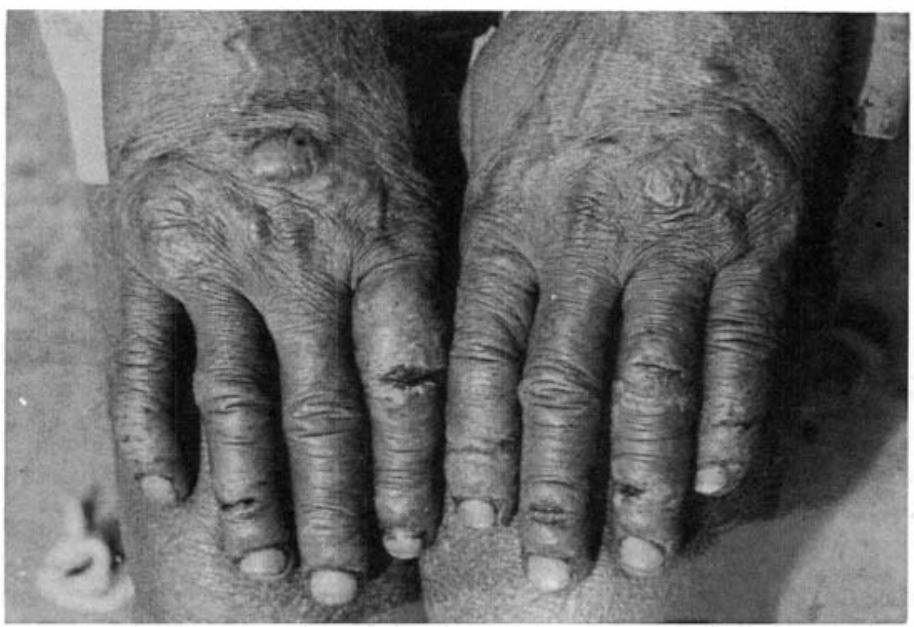

Figure 2.

smears stained with Ziehl-Neelsen's and Giemsa's stains for AFB and LeishmanDonovan (LD) bodies showed no organisms. On histopathology a diffuse dermal infiltrate of lymphocytes, numerous plasma cells and histiocytes with clear cytoplasm were seen. Occasional Russell bodies could be seen in the plasma cells. No organisms were seen on Fite-Faraco, Giemsa's and PAS stains. Culture of a nodule for leishmania parasite in NNN and Tobie's diphasic media was negative. A tentative diagnosis of PKDL was made and $10 \mathrm{ml}$ of sodium antimony gluconate equivalent to $1000 \mathrm{mg}$ of total antimony was given i.m. daily. Within a month the lesions showed signs of regression and antimony was continued, as were blood profile and liver function tests. Considerable improvement was seen at 3 months, and after 4 months of regular therapy with antimony the condition had regressed completely and the injections were stopped.

\section{Discussion}

PKDL exclusively affects the skin, appearing at times several years after an attack of kalaazar or rarely with no history of the disease. The lesions are protean in manifestation ranging from hypopigmented macules to erythematous plaques and nodules, mimicking leprosy at any time. They do not ulcerate and may be localized to the face where they tend to cluster centrally or are generalized. Demonstration of LD bodies in slit-skin smears and histopathology confirms PKDL but unlike AFB in LL, LD bodies have a typical appearance that cannot be mistaken, are highly variable and may be very difficult to demonstrate in some instances. ${ }^{2-4}$ The features suggestive of LL in our patient were (i) nodules and plaques in a symmetrical and bilateral distribution, (ii) facial and earlobe infiltration with some central clustering of the papules, and (iii) ulcers on the dorsa of the hands. The other important clinical findings of LL not seen in this patient were the absence of the lateral third of eyebrows, and nasal mucosal and nerve involvement. Repeated attempts to show AFB and LD bodies were unsuccessful. The presence of AFB 
reported by the previous pathologist were most likely confused with granules of mast cells and the sweat glands. ${ }^{5}$

Syphilis, rare fungal diseases like coccidioidomycosis, ${ }^{6}$ sarcoidosis, abnormal cellular infiltrates $^{7}$ and lymphoproliferative disorders that can present a similar picture were excluded by appropiate blood tests and histopathology. The diagnosis of PKDL was based on the previous history of kala-azar, the non-ulcera tive nature of the nodules and confirmed by the good therapeutic response to antinomy injections. The ulcers on hands were mainly due to repeated stretching as they involved the plaques on the sites of frequent mobility and possibly trauma. The other cause for nodules in PKDL to ulcerate is iatrogenic, when oral potassium iodide is used for therapy. ${ }^{8}$ Unlike PKDL, the nodules in lepromatous leprosy may ulcerate with an increase in size or during reaction. Hypopigmented macules in PKDL are generally small $(<1 \mathrm{~cm})$, multiple and irregular in configuration that may coalesce later, and are stationary and refractory to treatment. The macules in leprosy have ill- or relatively well-defined borders, show varying degrees of sensory impairment and left untreated they may increase in size or become indurated. Occasionally a wary clinician may encounter both leprosy and PKDL in the same patient. Other workers have also pointed out the remarkable similarity between leprosy and PKDL, both of which can have varied presentations on the skin, stressing the need for proper clinical and laboratory examination. ${ }^{9}$

This report exemplifies the words of $\mathrm{Khanolkar}^{10}$ who emphasized that it was not always possible to determine the aetiology of any chronic disease by either its clinical manifestations only or by its typical histological and immunological features. It then becomes necessary to rely on other factors like history, disease prevalence in a particular area and a therapeutic trial to clinch the diagnosis.

\section{References}

1 WHO Study Group. Chemotherapy of leprosy for control programmes. Technical Report Series No. 675. WHO: Geneva, 1982.

${ }^{2}$ Chatter jee KD. Dermal leishmanoid (post-kala-azar dermal leishmaniasis). In: Human parasitesandparasitic diseases, Calcutta, India, 1952, p 223.

${ }^{3}$ Majumdar TD. Post-kala-azar dernmal leishmaniasis. In: Essays on Tropical Dermatology, Simons RD, Marshall J (eds), Amsterdam: Excerpta Medica, 1969, p 195.

${ }^{4}$ Sen Gupta PC, Bhattacharjee B. Histopathology of post-kala-azar dermal leishmaniasis. J Trop Med Hyg, 1953; 56: 110-16.

5 Dharmendra, Chatterjee SN. The importance of early diagnosis. In: Leprosy, Dharmendra (ed), Bombay: Kothari Medical, 1978, p 271.

6 Hobbs RE, Hempstead RW. Cutaneous coccidioidomycosis simulating lepromatous leprosy. Int J Derm, 1984; 23: 334-336.

7 Singh K, Dawar R, Ramesh V. Lymphocytic infiltration of skin of Jessner-Kanof masquerading as borderline leprosy. Ind J Lepr, 1985; 57: 804-6.

8 Manson-Bahr PH. Leishmaniasis, In: Manson's Tropical Diseases, London: Cassell, 1960, p 147.

9 Girgla HS, Marsden RA, Singh GM, Ryan T J. Post-kala-azar dermal leishmaniasis. Br J Dermatol, 1977; 97: 307-11.

${ }^{10}$ Khanolkar VR. The importance of histopathological diagnosis. In: Leprosy in theory and practice, Cochrane RG, Davey TF (eds), Bristol: John Wright, 1964, p 149. 


\title{
Leishmaniose dermale post-kala-azar: un cas extrêmement pareille à la lèpre lépromatose
}

\author{
V Ramesh, Uma Saxena, R S Misra et A Mukherjee
}

Sommaire On décrit le cas d'un homme adulte avec leishmaniose dermale post-kala-azar dont les lésions étaient distribuées d'une façon extrêmement pareille à ce qu'on observe dans le cas de la lèpre lépromatose. Il a suivi un traitement à drogues multiples selon les récommendations du Comité des Experts sur la Lèpre de la OMS. Aucun des examens essayés - frottis de peau déchirée, histopathologie, culture pour Leishmania donovani et un essai d'anticorps fluorescents indirectes pour confirmer la leishmaniose dermale post-kala-azar, entre autres - a donné des résultats positifs. Eventuellement, le diagnostic à été basé sur le passé médicale de kala-azar du patient, la manque d'autres troubles prouvée par des analyses de laboratoire rélévantes et la bonne réaction au traitement de gluconat de sodium et d'antimoine. On discute l'importance épidémiologique de ce cas et les charactéristiques principales qui distinguent cette maladie de la lèpre.

\section{Leishmaniasis dermal post kala-azar: Informe de un caso muy parecido a la lepra lepromatosa}

\author{
V Ramesh, Uma Saxena, R S Misra y A Mukherjee
}

Resumen Se describe el caso de un hombre adulto padeciendo de leishmaniasis dérmica post kala-azar con lesiones distribuidas de modo muy parecido a la lepra lepromatosa. Recibió un tratamiento de terapia de drogas multiples según las recomendaciones del Comité de Expertos sobre la Lepra de la OMS. Ninguno de los exámenes llevados a cabo-entre otros, frotes de piel resquebrajada, histopatología, cultivos para Leishmania donovani y una prueba de anticuerpos indirectos fluorescentes para confirmar la leishmaniasis dérmica post kala-azar-dió resultado. El diagnóstico se basó eventualmente en el antecedente de kala-azar, la carencia de otros desordenes descontados por medio de pruebas de laboratorio adecuadas y la respuesta terapeutica positiva del paciente a un tratamiento de gluconato de antimonio y de sodio. Se discuten la importancia epidemiológica de este caso y las caracteristicas principales que distinguen esta af ección de la lepra. 